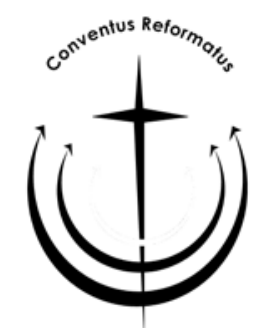

\title{
Calvin as an exegete of Scripture: a few remarks with reference to Calvin research in general
}

\author{
V.E. d'Assonville \\ Department of Ecclesiology \\ University of the Free State \\ BLOEMFONTEIN \\ Akademie für Reformatorische Theologie \\ HANOVER \\ Germany \\ E-mail:vicdas@xsinet.co.za
}
... fons omnis sapientiae est scriptura, unde haurire debent pastores quidquid proferunt apud gregem.
... Scripture is the fountain of all wisdom, from which pastors must draw all that they place before their flock. ${ }^{1}$

Article dedicated to the memory of André Malan Hugo (19291975), philologist and Calvin scholar.

\section{Abstract \\ Calvin as an exegete of Scripture: a few remarks with reference to Calvin research in general}

Calvin did not start his famous vocation as an interpreter of Scripture with Scripture itself. After a thorough training in interpreting classical literature as a philologist, he made his debut before turning 23 , with a highly respected commentary on Seneca's "De Clementia". His focus shifted to Scripture shortly thereafter. Certain features of his exegetical approach as part of his "Word of God theology" can thus be observed, especially as

1 Commentary on 1 Timothy 4:13 (Donec venio, attende lectioni, exhortationi, doctrinae.); CO 52,302,line 36-40: "Notandus etiam est hic ordo, quod lectionem doctrinae et exhortationi praeponit. Nam certe fons omnis sapientiae est scriptura, unde haurire debent pastores quidquid proferunt apud gregem." 
they relate to his use of the concept of "doctrina". His exegesis used not only the principle of "sola Scriptura" as point of departure, but also the principle of "tota Scriptura", i.e. to take the whole of Scripture into account when expositing a certain biblical text. For Calvin the original intention of the writer of a particular (Bible) book is of crucial importance. The exegesis should be done using a sound theological-methodological, historical-grammatical method. Knowledge of the original languages of Scripture is therefore a prerequisite for any exegesis. In his exegesis Calvin emphasises the point that Scripture as the Word of God and the Holy Spirit cannot be separated. As the truth is simple, Calvin avoids any traces of allegory in his exegetical activities and aims to keep his exegesis and exposition of Scripture simple, brief, clear and understandable exegesis should always exhibit the quality of clarity and brevity. In all exegesis, Scripture as the Word of God should be accepted as the final authority on any issue, not the church as institute.

\section{Opsomming}

\section{Calvyn as eksegeet van die Skrif: enkele opmerkings met verwysing na Calvynnavorsing in die algemeen}

Die uitlewing van sy roeping as beroemde eksegeet van die Skrif het vir Calvyn nie met die Skrif self begin nie. Ná 'n deeglike skoling as filoloog in die uitleg van klassieke literatuur het hy sy buiging reeds voor sy $23 e$ verjaarsdag met ' $n$ indrukwekkende kommentaar op Seneca se "De Clementia" gemaak. Vandat hy kort daarna begin het om sy volle aandag aan die Skrif te gee, kan bepaalde kenmerke van sy eksegetiese benadering as deel van sy "Woord van God-teologie" in sy geskrifte waargeneem word, in die besonder aan die hand van sy gebruik van die begrip "doctrina". Calvyn se eksegese het nie slegs die "sola Scriptura"-beginsel as vertrekpunt nie, maar ook die "tota Scriptura"-beginsel - met ander woorde om die Skrif in sy geheel in aanmerking te neem by die verklaring van 'n bepaalde Skrifteks. Vir Calvyn is die oorspronklike bedoeling van 'n spesifieke (Bybelse) boek van deurslaggewende betekenis. Die eksegese moet gedoen word deur 'n begronde teologies-metodologiese histories-grammatiese metode. Kennis van die oorspronklike tale van die Skrif is dus 'n onmisbare voorvereiste vir enige eksegese. In sy eksegese beklemtoon Calvyn dat die Skrif as Woord van God en die Heilige Gees nie geskei kan word nie. Aangesien die waarheid eenvoudig is, word enige spoor van allegorie vermy. Die doel is dat die eksegese en uitleg van die Skrif eenvoudig, kort, helder en verstaanbaar sal wees - eksegese moet altyd die kenmerk van helder beknoptheid toon. In alle eksegese moet die Skrif as 
Woord van God as finale gesag oor enige kwessie aanvaar word, nie die kerk as instituut nie.

\section{From an interpreter of classical literature to a "theologian of the Word" ${ }^{2}$}

A few years before Calvin would become internationally famous for his achievements in the exposition of biblical texts, he was already an interpreter of literature, though not yet of Scripture. His 1532 commentary on Seneca's De Clementia ${ }^{3}$ (cf. Peter \& Gilmont, 1991:30-34) has proven to be an accomplishment of astonishing excellence. At that time, however, it was not as highly esteemed among the European scholars (cf. Neuser, 2009:54), as Calvin had perhaps expected, after finishing it at a mere age of 22. Furthermore, it was not really acknowledged among his own colleagues, nor by Calvin biographers and researchers of later ages (cf. Hugo, 1957:xiii, xiv). 4 Nevertheless, it is fairly well-known that Calvin's abilities as a scholar of the art of interpretation enjoyed high recognition

2 I would like to express thanks for permission by the editor of the Calvin Handbuch, Prof. H.J. Selderhuis, to adapt my contribution and use the research results (d'Assonville, 2008) in this article. Furthermore, part of the research presented in this article was used, on request, in a paper at the Reformierte Sommer Universität on "Reformed hermeneutics", organised by the Reformiertes Seminar, Evangelisch-Theologische Fakultät, Westfälische-WilhelmsUniversität and the Theologische Universiteit Apeldoorn in Münster, Germany, on 27 August, 2009.

"L. Annei Senecæ, romani senatoris, ac philosophi clarissimi, libri duo de clementia, ad Neronem Cæsarem: Joannis Calvini Noviodunæi commentaries illustrate." Cf. Calvin (1969:4-381).

This article is dedicated to the memory of the late André Malan Hugo (19291975), Calvin scholar, historian and philologist. It is a pity that Hugo, one of the most renowned Calvin researchers of the twentieth century, who did pioneering research on Calvin's study on Seneca, is not recognised adequately in his home country, South Africa. His dissertation (Hugo, 1957) on Calvin's commentary on Seneca's De Clementia ranks among one of only a few South African dissertations in the twentieth century to obtain wide international recognition (cf. Britz \& d'Assonville, 2008:501). Special mention must be made of the publication of Calvin's text with introduction, translation and notes by Hugo in cooperation with the famous American Calvin scholar, Ford Lewis Battles (Calvin, 1969), which has set such a high standard of editing skills, that this source does not even have to be republished in the new COR-series. Hugo not only did his research in the Netherlands and in France, receiving his Doctor's degree from the Rijksuniversiteit Utrecht, but he also wrote his famous dissertation in Dutch - not an easy accomplishment for an Afrikaans-speaking researcher. 
during his lifetime and thereafter - even among his Roman adversaries (cf. Burger, 2008:142).

It is thus appropriate to pay attention to Calvin as an exegete, i.e. as an interpreter of Scripture, particularly within the context of the celebration in 2009 of Calvin's birthday 500 years ago. Not only is the Calvin Year cause for much reflection on Calvin, his work and his influence, but these days are also marked by heated discussions on hermeneutics, Scripture and the authority of Scripture. A mere glance at some important recent publications dealing with Calvin and these themes confirms their significance in Calvin research, e.g. Opitz (1994); Greene-McCreight (1999); Van 't Spijker (2001); Balke (2003); Thompson (2000; 2004); De Greef (2006); Raynal (2006); and McKim (2006) to name but a few. 5

Further mention should be made of recent studies on the humanistic aspects (humanistic in a technical sense of the word) of Calvin's exegesis, of which the most important publication is the standard work by Millet (1992). However, it is beyond the scope of this article to zoom in to this essential facet of sixteenth century exegesis, especially as utilised by Calvin (cf. Britz \& d'Assonville, 2009:469). 6

5 Of course many more studies on Calvin as exegete could be mentioned here, e.g. Parker (1980; 1993a; 1993b); Ganoczy and Müller (1981); Ganoczy and Scheld (1983), of which the introductions to his commentaries in the new CORseries are perhaps the most important. The purpose of this article though is not to be comprehensive with regard to the secondary literature on this topic.

Britz and d'Assonville (2009:469):

Regarding the question of which exegetical method underpinned the foundation of Calvin's Roman commentary, it has been pointed out many times that the exegetical weight assigned by Calvin to the text of the letter to the Romans has a connection with the humanistic rhetoric of the sixteenth century, through which he was also trained. (The concept humanistic is here used in a technical sense, as it prevailed at the time. It referred to the methods and instruments of the study of (foremost antique) texts, in other words, knowledge of the basic languages (albeit Greek, Hebrew or Latin), control over philology, grammar and using the auxiliary means of semantics, and so on.) This method entailed that a reliable understanding of the text had to be attained through knowledge of the text (through its meanings it became accessible in other words), that the scopus of the text had to be found within the larger textual coherence (context), that the central themes of the text were identified, that the cultural-historical context within which it obtained its form was known and that the history of interpretation (the history of the exegesis) was also known. In other words, it concerned the question regarding the mastery of the text under consideration - as explicated in the course of history. What is of particular importance is that the thought orientation and aims of the original author had to be taken into consideration. 


\section{Calvin's exegesis according to his use of the concept of doctrina}

In the sixteenth century the use of the concept of doctrina revealed much about an author's view of Scripture, of revelation and proclamation as well as his Christology and ecclesiology. Moreover, an analysis of the use of this concept also gives us an indication of how central the role and significance of the exegesis of Scripture is in the writings of an author.

Calvin's theology, which has often been characterised as a "theology of the Word", 7 presupposes a certain view of exegesis, which is presented in this article - with special reference to his use of the concept of doctrina. This is done with reference to general Calvin research, especially concerning the matter of methodology. Although several studies have been done on Calvin's use of the concept of doctrina (cf. D'Assonville, 2001:18-22), most of them focus on the proclamation character of the doctrina, or even the revelation character of it. What it means for his exegesis in particular has not been examined, with the small exception of Opitz (1994:104-116, $245 \mathrm{ff}$.$) , although in his case the emphasis is more on Calvin's view$ of God's Word.

Against this background Calvin's usage of the concept of doctrina in his writings is noteworthy. Already in 1536, in the introductory sentence of the first edition of his Institutes, he speaks about the summa of the sacra doctrina (OS I,37), which was changed in the succeeding editions to the tota ... summa of the sapientia (OS III,31,6). This concept is used often and strikingly throughout his writings. Valuable features regarding his exegesis can be derived from this usage. Two aspects are to be considered in this regard: on the one hand, it is revealing to see how Calvin's understanding and exposition of Scripture correlates with his usage of the concept of doctrina. On the other hand, the way we read and interpret Calvin's works should take into account this application of the concept of doctrina.

\section{Methodology and Calvin research}

A glance at Calvin's works thus suffices to see that they are characterised by his use of this term. That the concept of doctrina was widely used in the sixteenth century - in discussions as well as 
in works of a theological nature - is not contested. How it was used is, however, not so evident to the current understanding of the concept. Time and again a lack of awareness in this matter has led to various misinterpretations of Calvin. Therefore - as should be the case in all Calvin research - one should work methodologically speaking very thoroughly. 8

A good example of a misinterpretation arising from an incorrect reading of the doctrina concept, is found in Bouwsma. Bouwsma (1989:98 ff.) judges Calvin's thinking as "rational" and "intellectual". He builds his case inter alia on Calvin's use of doctrina (Latin) or la doctrine (French), which he translates with the English doctrine (Bouwsma, 1989:99). This is a typical error, in which a sixteenthcentury Latin or French concept is translated with a word that sounds similar in a modern language, but differs conceptually - in this case an English/American concept. This easily leads to an inadequate interpretation of Calvin. Bouwsma for example states:

... These convictions were reflected in an emphasis on the Gospel as doctrine. Its importance was implied in Paul's warning to Timothy [2 Tim. 1:13 - VEd'A], Calvin argued, 'not to depart from the form of teaching he had received'; because 'the least deviation from doctrine is exceedingly harmful'. Doctrine, he pointed out [in a sermon on Job 21:1-6 - VEd'A], 'is a great deal more precious than persons'. Such sentiments point to a tendency in Calvin to understand faith less as trust in God's promises than as intellectual assent to a body of propositions. (Bouwsma, 1989:99.)

Not only does Bouwsma translate doctrina incorrectly with doctrine, but he also quotes Calvin in an eclectic way, without regard for the

8 Methodologically speaking, an analysis of the handling of the doctrina concept by Calvin - actually all Calvin research - requires a number of guidelines, which are crucial for any Calvin research. Suffice it to say that using the primary sources in the original languages is of extreme importance. Any study on Calvin which is content itself with using translations only is doomed to arrive at onesided and incorrect conclusions. With this as a premise there are some essential methodological guidelines. Although these parameters for reading texts are self-evident, it is disappointing to note how often they still are neglected in Calvin studies. First of all, the time period in which a specific writing originated, together with its historical setting and context, should always be taken into consideration. Secondly, the genre of the writing (e.g. commentaries, tractates, sermons, polemical writings, Institutes, etc.) is of decisive importance when analysing Calvin's work. Thirdly, respective writings of Calvin should, as far as possible, be treated as a whole in order to refrain from using singular citations from different works in a way that does violence to the original context. 
different genres and time periods constitute the full range of his output. This not only gives rise to an incorrect conclusion, but also casts a shadow on Bouwsma's methodology. 9

\section{A biblical and theological concept}

As part of his exegetical activities Calvin, in the course of time, translated most of the books of the Old and New Testament from the original Hebrew and Greek texts respectively into either Latin or French. He had a number of printed Greek texts at his disposal, when he worked on the New Testament. In the process of translating the Greek text - always favouring a source-text oriented, grammatical-historical concordant translation - he often engaged in a discourse with the Vulgate as well as with Erasmus's Latin edition. Consequently the Latin concept of doctrina was not only a useful tool for Calvin in expressing himself theologically, but was also presented to him as a biblical concept, whether in the Vulgate or in Erasmus's translation (or even in other Latin translations, like that of Jacques Lefevre d'Estaples, i.e. Jacobus Faber Stapulensis) or, of course, in his own translation.

As doctrina in the sixteenth century was a concept used frequently and generally without ambivalence regarding its meaning or theological implications, its lexicographical sense was very clear. This was also the case concerning the discourse-analytical (referential) way it was used within different semantic domains. Therefore, Calvin did not find it necessary to define or to explain his usage of doctrina. His use of this concept, however, is distinctive with respect to the way that it usually bears reference to the Holy Scripture (sacra Scriptura). This does not mean that Calvin does not distinguish between doctrina and Holy Scripture, but it is a matter of concern to him to stress, in particular, the authority, source and foundation of the doctrina, which rests in Christ (cf. Comm. on 2 Tim. 4:3-4; CO 52,386 ), which comes from the mouth of God (Comm. on Tit. 1:7-9; CO 52,412) and is in accordance with Scripture (1535, A tous amateurs ... - preface to the French Bible translation of Olivétan; CO 9,817). Scripture is the source of the doctrina (Comm. on 2 Tim. 3:16; CO 52,383-384). Calvin's theological foundation in Scripture and his emphasis on doctrina as proclamation serve to highlight his Word of God theology (cf. OS I,129; 144; Neuser, 1998:243).

$9 \quad$ See footnote above on methodology. 


\section{Sola Scriptura and tota Scriptura: Scripture alone and the whole Scripture}

Since Calvin mostly speaks of doctrina in its entirety, i.e. as a whole, as one doctrina, it presumes the unity of Scripture as the Word of God. There is one Truth of God (una est Dei veritas - Comm. on 1 Tim. 1:3; CO 52,251). Hence, Calvin's "hermeneutics has the tota Scriptura as point of departure" (Van 't Spijker, 2001:J209). However, as doctrina is a dynamic, active concept, sola et tota Scriptura in this sense does not imply a formal, legalistic or biblicist view of Scripture or method of exegesis. On the contrary, by dealing with Scripture as a whole (una et tota Scriptura), by operating with one doctrina, which originates from Christ (Responsio ad Sadoleti epistolam, 1539; OS I,466; Comm. on 2 Tim. 4:3-4; CO 52,386), one avoids exegesis that uses statements or citations from Scripture in an eclectic way, as a kind of dicta probantia, without taking their biblical-historical context into consideration. The original intention of the writer of a particular (Bible) book is of exceptional importance for Calvin: for an expositor of Scripture, "it is almost his only work to lay open the mind of the writer whom he undertakes to explain" (Dedication letter to Grynaeus in Comm. on Rom.; COR II/XIII,3). This should be done using a sound theological-methodological, historical-grammatical method of exegesis. Knowledge of the original languages of the Bible - Hebrew and Greek - is therefore a prerequisite for any exegesis. In Calvin's thinking, the key to arriving at the intention of the original writer is found in the consistent grammatical analysis of the text in the original language, within its narrow and broad Scriptural context, taking the genre of the specific part of the text into consideration, as well as the historical setting.

\section{Word and Spirit}

Where Scripture is concerned, the intrinsic bond between the Word and the Holy Spirit is theologically presupposed in Calvin's thinking. In his reply to the letter of Sadoletus (Responsio ad Sadoleti epistolam, OS I,457-489), Calvin accentuates this point particularly: Scripture as the Word of God and the Holy Spirit cannot be separated. Calvin's emphasis is a corrective to both the Roman Church, with its insistence on the authority of the church, as well as to the Anabaptists, with their claims regarding the Spirit within them.

The Spirit has bound Himself irrevocably to his Word. The Spirit has been promised not to reveal a new doctrina, but to impress the truth of the gospel on our minds ("spiritus sit promissus non ad novam doctrinam revelandam, sed imprimemdam hominum animis evan- 
gelii veritatem" - OS 1,465). It is not possible to claim that the church is governed by Christ, while God's Word is simultaneously subjugated to the authority of men/the church ("the tendency is to ... bury the Word of God" - OS 1,465). The Spirit goes before the church to enlighten her in understanding the Word - all doctrinae should be tested/proved by the Word, i.e. Scripture (OS 1,465,466). On these grounds Calvin defines the church as "the society of all the saints, a society which, spread over the whole world, and existing in all ages, yet bound together by the one doctrina of Christ, and the one Spirit, cultivates and observes unity of faith and brotherly concord" (OS I,466). By persevering in the sound faith (in sana fide), a faithful testimony (fidele testimonium) to sana doctrina is rendered (cf. Comm. on Heb. 13:7; COR II/XIX,237). Sana doctrina, which is occasionally characterised by Calvin as doctrina of Christ (doctrina Christi - Comm. on 2 Tim. 4:3; CO 52,386), is, however, no rational, intellectual concept - as it was seen by scholastic theologians - but refers directly to life (vita) (Comm. on 1 Tim. 6:3, 4; CO 52,256).

\section{Simplex doctrina - no allegory}

In his exegetical denunciation of the fabulosa dogmata of the Roman Church and the speculative theology of the scholastic (Roman) theologians, Calvin underlines the simplicity of the doctrina. Already in the first edition of his Institutes (1536) he writes: "The book [i.e. the Institutes] witnesses that this was my intention, adapted as it is to a simple and, you may say, elementary form of teaching" (OS I,21), an intention to which he kept until the final (Latin) edition of the Institutes in 1559 (cf. OS III,9,12/13) as well as in his commentary on the Psalms (CO 31,33). Like the sixteenth-century humanists, Calvin can state that the truth is simple. A simple and elementary form of teaching (doctrina) is deliberately presumed as a contrast to the scholastic philosophy and theology of that time (Comm. on 1 Tim. 1:3; CO 52,251). The truth is simple and clearly visible (Inst. 4.17.32; OS V,391,9).

Indeed, in his exegetical activities Calvin aimed to keep his exegesis and exposition of Scripture simple, brief, clear and understandable. In the second edition of the Institutes (1539) he states that his intention is to "give a simple outline of doctrina as briefly (brevitate) as possible" (Inst. 3.6.1; OS IV,147,8-10). Later on, in the last Latin edition (1559) he would add: "By nature I love brevity" (Amo natura brevitatem) (Inst. 3.6.1; OS IV,147,5/6). When he had to choose between different interpretations, he preferred the simpler and more self-evident solution (OS I,172). 
However, it is not only the humanistic method of the sixteenth century which was promoted by Calvin. For him it was more than a question of method. In his methodology, his attention was directed towards the evangelical contents of the biblical text. The sana doctrina is the simple, clear-cut (simplex) doctrina of the gospel (evangelii) (Comm. on 2 Tim. 4:4; CO 52,387). This premise of Calvin is based on his conviction that the gospel, the Word of God, is simple. Everyone can understand the gospel. Therefore, all exegesis should exhibit the quality of clear brevity ("in perspicua brevitate" - Dedication letter to Grynaeus in Comm. Rom., COR II/XIII,3). To the extent that Calvin wanted to restrict himself to the literal, simple meaning of the text he rejected any form of allegory (Inst. 2.5.19; OS III,319,9 ff.; Comm. on 2 Cor. 3:6; CO 50). There is only one meaning of the text, namely that which was expressed by the original author. Calvin's focus on the text itself presupposes a rejection of using allegory hermeneutically (cf. Opitz, 1994:40).

\section{Ecclesiological consequences}

Calvin's Word of God theology has significant ecclesiological consequences. Besides appealing to the Early Church concerning the doctrina ("Neque vero in doctrina dubitamus ad veterem ecclesiam provocare" - OS 1,467), Calvin highlights the recognition that God is a speaking God (Deus loquens - Inst. 1.7.4; OS III,68,30-69,1). The final authority on any issue is Scripture as the Word of God. Calvin's insistence on the fact that God uses his mouth to teach us (Inst. 1.6.1; OS III,60/61) implies that the church is, according to the reformed view, a church of the Word - in contrast with the Roman view of the church as a sacramental church (according to which grace is received through the sacraments).

The doctrina (preaching of the gospel), together with the disciplina (church discipline) and the sacraments form the sound basis on which the church is founded (OS 1,467). As distinct from the Confessio Augustana article 7, where (in the Latin text) the doctrina evangelii together with the administratio sacramentorum are stated as marks of the church (notae ecclesiae), Calvin's influence on the Confessio Belgica is apparent (cf. the pura evangelii praedicatio, the sincera sacramentorum administratio and the disciplina ecclesiastica as notae ecclesiae according to the Confessio Belgica article 29). In the light of this it is logical to comprehend why Calvin time and again emphasises the prerequisite of the doctrina in its relation to faith as well as to the church. As faith (fides) is the principal matter (summa) of doctrina in Calvin's thinking, faith in Christ is most essential 
regarding the concept of doctrina (Comm. on 2 Tim. 3:16; CO $52,384)$. Doctrina should always build up the faith as well as build up/edify (aedificare) the church (Comm. on 1 Tim. 6:2b-3; CO 52,323-324; cf. d'Assonville, 2003). The doctrina accomplishes this objective in three ways: it teaches (instruare), it builds up (aedificare), and it educates (erudiare). Together with another key term, praedicatio (which covers only a limited part of the semantic range of doctrina), doctrina indicates an inclusive comprehension of proclamation. The church is bound by the one doctrina of Christ, and by the singular, one Spirit, (OS I,466). It is therefore quite understandable when Calvin, distinguishing between meaning (sensus) and usefulness (usus) of the text (Opitz, 1994:44), states that he wants to benefit the church of God by his exegesis (COR IIIXIII,3,26).

In Calvin's Word of God theology, in which the doctrina Christi is directly connected to Scripture as the Word of God, his view on the four offices in the church (ministers/pastors, doctors of the church, elders and deacons) agrees in all respects with the indivisible, intrinsic relation of doctrina with exegesis of Scripture, proclamation of the gospel, exhortation and works of mercy (by the deacons).

\section{Semantic range}

The range of semantic applications of Calvin's uses of the concept of doctrina is surprisingly broad. He uses it in a classical-philological way (meaning erudition/learning/learnedness, e.g. in COR II/XIII, 3,34 , teaching/instruction) as well as in the biblical way, with reference to the Greek terms didaskalia/didache. He uses the concept in a dynamic, active way with verbal dimensions (cf. docere - to teach), to be translated with a verb, a verbalised noun or even a verbal phrase. However, it can also have nominal dimensions (e.g. teaching, sermon). He also uses the concept to denote something active (e.g. the teaching of something) as well as something static (e.g. doctrine). The scale ranges from summary or focus of Scripture, the gospel, contents of faith, exposition, proclamation of salvation, via teaching or sermon to pastoral care, confession, doctrine, canon, dogma or doctrinal system (d'Assonville, 2001:201).

By recognising this, the Calvin interpreter and researcher will ensure that he pays attention to the subtle, yet significant distinctions and nuances of Calvin's usage of this concept, instead of reading some arbitrary lexicographical meaning into his texts. A good illustration of this can be found in Book 2 of the Institutes (Inst. 2.9.2; OS III,399,27 ff.). When Calvin expounds 1 Tim. 4:6, he explains why 
Paul characterises the gospel (evangelium) as the fidei doctrina. Calvin even occasionally interchanges the concept evangelium with doctrina (e.g. Comm. on 1 Tim. 6:1; CO 52,323) - a reference to the source and authority of the doctrina, namely Christ (cf. Comm. on 2 Tim. 4:3-4; CO 52,386).

\section{Conclusion}

Calvin's theological usage of the concept of doctrina is remarkable. When Calvin uses the concept of doctrina it is never intended to denote doctrine of dogma in a negative or static way. Consequently, exegesis and dogmatics are not separated. Biblical and systematic theology or dogmatics, systematic theology and pastoral or practical theology are in harmony. To state it in stronger terms: for Calvin, all these different fields of theology are parts of one unified body of theology, which, as a whole, cannot be divided or separated. This insight has essential consequences for theology in general, for the teaching and tutoring of pastors, but in particular for the methodology of Calvin research as well as for exegesis. One should not forget that Calvin's accomplishments and achievements as a theologian at the highest theological-scientific level, can never be separated from his labours in ministering the Word in the congregation. In his writings there is no contradiction between preaching and apologetics, no opposition between pastoral care and systematic dogmatics, no tension between proclaiming the Word, missionary work and theological exegesis. For Calvin indeed "... Scripture is the fountain of all wisdom from which pastors must draw all they place before the flock". 10

\section{List of references}

BALKE, W. 2003. Calvijn en de Bijbel. Kampen: Kok.

BOUWSMA, W.J. 1989 [1988]. John Calvin: a sixteenth-century portrait. New York: Oxford University Press.

BRITZ, R.M. \& D'ASSONVILLE, V.E. 2008. Die Rezeption Calvins in Afrika. (In Selderhuis, J., Hrsg. Calvin Handbuch. Tübingen: Mohr Siebeck. S. 498504.)

10 CO 52,302, line 36-40: "Notandus etiam est hic ordo, quod lectionem doctrinae et exhortationi praeponit. Nam certe fons omnis sapientiae est scriptura, unde haurire debent pastores quidquid proferunt apud gregem." cf. d'Assonville (2001:156): “... für Calvin ist die Schrift durchgehend als 'fons omnis sapientiae' grundlegend". 
BRITZ, R.M. \& D'ASSONVILLE, V.E. 2009. 'n "Toegang tot verstaan van die ganse Skrif": Calvyn se eerste Bybelkommentaar in histories-teologiese perspektief. (In Strauss, D.F.M., red. Spesiale uitgawe - Johannes Calvyn. Tydskrif vir Geesteswetenskappe, 49(3):467-486, Sept.)

BURGER, C. 2008. Calvin und die Humanisten. (In Selderhuis, J., Hrsg. Calvin Handbuch. Tübingen: Mohr Siebeck. S. 137-143.)

CALVIN, J. 1863-1900 [1531-1564]. Ioannis Calvini opera quae supersunt omnia, Vol. I-LIX. 1863-1900. Ediderunt G[W]. Baum, E. Cunitz \& E. Reuss, Vol. I-LIX, in Corpus Reformatorum, Vol. XXIX-LXXXVII. Brunsvigae/Berolini: Schwetschke. [= CO 1-59.]

CALVIN, J. 1926-1962. Joannis Calvini opera selecta, Vol. I-V. 1926-1962. Ediderunt P. Barth, G.(W.) Niesel \& D. Scheuner. Monachii in Aedibus [München]: Chr. Kaiser. [= OS I-V.]

CALVIN, J. 1969 [1532]. L. Annei Senecæ, romani senatoris, ac philosophi clarissimi, libri duo de clementia, ad Neronem Cæsarem: Joannis Calvini Noviodunæi commentaries illustrate. (In Battles, F.L. \& Hugo, A.M., eds. Calvin's commentary on Seneca's De Clementia with introduction, translation, and notes. Part two. Leiden: Brill/The Renaissance Society of America. p.1-381.)

CALVIN, J. 1996 [1549]. In Calvinus, I. Commentarius in Epistolam ad Hebraeos. (Edidit T.H.L. Parker. Ioannis Calvini opera omnia: Denuo recognita et adnotatione critica instructa notisque illustrata, Series II: Opera exegetica Veteris et Novi Testamenti, Volumen XIX. Auspiciis Praesidii Conventus Internationalis ediderunt B.G. Armstrong, C. Augustijn, I. Backus, O. Fatio, H. Feld, F.M. Higman, W.H. Neuser, B. Roussel, W. van 't Spijker \& D.F. Wright. Genève: Droz.) [= COR II/XIX.]

CALVIN, J. 1999 [1540; 1551; 1556]. In Calvinus, I. Commentarius in epistolam Pauli ad Romanos. (Ediderunt T.H.L. Parker et D.C. Parker. Ioannis Calvini opera omnia: Denuo recognita et adnotatione critica instructa notisque illustrata, Series II: Opera exegetica Veteris et Novi Testamenti, Volumen XIII. Auspiciis Praesidii Conventus Internationalis Studiis Calvinianis Fovendis ediderunt B.G. Armstrong, C. Augustijn, I. Backus, O. Fatio, H. Feld, F.M. Higman, W.H. Neuser, B. Roussel, W. van 't Spijker \& D.F. Wright. Genève: Droz.) [= COR II/XIII.]

$\mathrm{CO}$ [= Calvini opera omnia/Corpus Reformatorum] see CALVIN, J. 1863-1900 [1531-1564]

COR [= Calvini opera recognita] see CALVIN, J. 1996 and 1999

D'ASSONVILLE, V.E. 2001. Der Begriff "doctrina" bei Johannes Calvin - eine theologische Analyse. Münster/Hamburg/London: LIT-Verlag.

D'ASSONVILLE, V.E. 2003. Woordverkondiging by Calvyn - enkele implikasies vir die opbou van die kerk in Afrika. Nederduitse Gereformeerde teologiese tydskrif, 44(3 \& 4):266-275.

D'ASSONVILLE, V.E. 2008. Exegese und Doctrina. (In Selderhuis, J., Hrsg. Calvin Handbuch. Tübingen: Mohr Siebeck. S. 372-378.)

DE GREEF, W. 2006. Calvijn en zijn uitleg van de Psalmen: een onderzoek naar zijn exegetische methode. Kampen: Kok. 
GANOCZY, A. \& MÜLLER, K. 1981. Calvins handschriftliche Annotationen zu Chrysostomus: ein Beitrag zur Hermeneutik Calvins. Wiesbaden: Franz Steiner. (Veröffentlichungen des Instituts für Europäische Geschichte Mainz. Bd. 102: Abteilung für Abendländische Religionsgeschichte. Herausgegeben von Peter Meinhold.)

GANOCZY, A. \& SCHELD, S. 1983. Die Hermeneutik Calvins. Geistesgeschichtliche Voraussetzungen und Grundzüge. Wiesbaden: Franz Steiner. (Veröffentlichungen des Instituts für Europäische Geschichte Mainz. Bd. 114: Abteilung für Abendländische Religionsgeschichte. Herausgegeben von Peter Manns.)

GREENE-McCREIGHT, K.E. 1999. Ad litteram: how Augustine, Calvin and Barth read the "plain sense" of Genesis 1-3. New York: Peter Lang.

HUGO, A.M. 1957. Calvijn en Seneca: een inleidende studie van Calvijns commentaar op Seneca, De Clementia, anno 1532. Groningen: Wolters.

McKIM, D.K., ed. 2006. Calvin and the Bible. Cambridge: Cambridge University Press.

MILLET, O. 1992. Calvin et la dynamique de la parole: etude de rhétorique réformée. Paris: Librairie Honoré Champion. (Bibliothèque Littéraire de la Renaissance, Série 3, Tome XXVIII.)

NEUSER, W.H. 1976. Theologie des Wortes - Schrift, Verheißung und Evangelium bei Calvin. (In Neuser, W.H., Hrsg. Calvinus Theologus: die Referate des Europäischen Kongresses für Calvinforschung vom 16. bis 19. September 1974 in Amsterdam. Neukirchen: Neukirchener. S. 17-37.)

NEUSER, W.H. 1998. Dogma und Bekenntnis in der Reformation: Von Zwingli und Calvin bis zur Synode von Westminster. 2. Aufl. (In Andresen, C. \& Ritter, A.M., Hrsg. Handbuch der Dogmen- und Theologiegeschichte, Band 2. Überarbeitete und ergänzte Ausgabe. Göttingen: Vandenhoeck \& Ruprecht (UTB). S. 167-352.)

NEUSER, W.H. 2009. Johann Calvin - Leben und Werk in seiner Frühzeit 1509-1541. Göttingen: Vandenhoeck \& Ruprecht.

OPITZ, P. 1994. Calvins theologische Hermeneutik. Neukirchen: Neukirchener.

OS [= Calvini opera selecta] see CALVIN, J. 1926-1962

PARKER, T.H.L. 1980. Calvin the exegete: change and development. (In Neuser, W.H., Hrsg. Calvinus ecclesiae doctor: die Referate des Internationalen Kongresses für Calvinforschung vom 25. bis 28. September 1978 in Amsterdam. Kampen: Kok. p. 33-46.)

PARKER, T.H.L. 1993a [1971]. Calvin's New Testament Commentaries. 2nd ed., re-edited. Edinburgh: Clark.

PARKER, T.H.L. 1993b [1986]. Calvin's Old Testament commentaries. 2nd ed., repr. Edinburgh: Clark.

PETER, R. \& GILMONT, J.-F. 1991. Bibliotheca Calviniana. Les œuvres de Jean Calvin publiées au xvie siècle, I: Écrits théologiques, littéraires et juridiques 1532-1554. Genève: Libraire Droz. (Travaux d'Humanisme et Renaissance, CCLV.)

RAYNAL, C., ed. 2006. John Calvin and the interpretation of Scripture. Papers presented at the 10th and 11th Colloquiums of the Calvin Studies Society at Columbia Theological Seminary. Grand Rapids: Calvin Studies Society. (Calvin Studies X and XI.) 
THOMPSON, J.L. 2000. Calvin's exegetical legacy: his reception and transmission of text and tradition. (In Foxgrover, D., ed. The legacy of John Calvin. Papers presented at the 12th Colloquium of the Calvin Studies Society. Grand Rapids: Calvin Studies Society. p. 31-56.)

THOMPSON, J.L. 2004. Calvin as a biblical interpreter. (In McKim, D.K., ed. The Cambridge Companion to John Calvin. Cambridge: Cambridge University Press. p. 58-73.)

VAN 'T SPIJKER, W. 2001. Calvin: Biographie und Theologie. (In Moeller, B., Hrsg. Die Kirche in ihrer Geschichte - ein Handbuch. Band 3, Lieferung J 2. Göttingen: Vandenhoeck \& Ruprecht.)

\section{Key concepts:}

Calvin

Calvin research

doctrina

exegete/exegesis

methodology

Scripture

\section{Kernbegrippe:}

Calvyn

Calvynnavorsing

doctrina

eksegeet/eksegese

metodologie

Skrif 
